UDK 005.574:630

UDK 316.485.6:630

Original scientific paper

\title{
ATTITUDES OF EMPLOYEES ABOUT CONFLICTS IN THE FORESTRY SECTOR
}

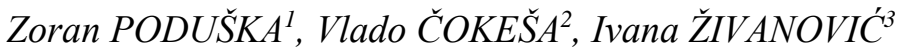

\begin{abstract}
The paper presents the research results on conflicts in the forestry sector. The theoretical framework of the research is based on the belief that conflicts are a universal phenomenon. The basic constituents of conflicts are elements and aspects. The elements of conflicts are the substance, processes and relations between participants, which affect the social, cultural, institutional and economic aspects. They also include the aspect of natural resources, which is a feature of the forestry sector. Such a theoretical framework gave grounds for the analysis of employees' opinions about the type and significance and the stage in which the observed conflicts were. The opinions of the people employed in enterprises and organizations benefiting from state forests, protected areas and administrative state bodies in the forestry sector were collected through a survey. The data collected were processed using descriptive statistics. A lot of conflicting situations were identified and they were classified into 10 groups. The most serious one is the conflict between regular measures and works in the forest of nature protection. Nine participants were identified in these conflicts. It was found that some conflicts had been resolved, while some were in the latent phase, with the possibility to escalate.
\end{abstract}

Keywords: conflict, forestry, nature protection

\section{STAVOVI ZAPOSLENIH O KONFLIKTIMA U SEKTORU ŠUMARSTVA}

Izvod: $U$ radu su prikazani rezultati istraživanja konflikta u sektoru šumarstva. Teorijski okvir istraživanja baziran je na stavu da su konflikti opšta pojava. Sastavni

\footnotetext{
${ }^{1}$ Dr sci Zoran Poduška, Institute of Forestry, Kneza Višeslava 3, Belgrade, Serbia; e mail:

Zoran.Poduska@gmail.com, phone: +381628838025 - corresponding author

${ }^{2} \mathrm{Mr}$ Vlado Čokeša, , Institute of Forestry, Kneza Višeslava 3, Belgrade, Serbia

${ }^{3}$ Dipl. eng. Ivana Živanović Radovanović, Institute of Forestry, Kneza Višeslava 3, Belgrade, Serbia
} 
delovi konflikta su elementi $i$ aspekti. Elementi su:suština, proces i relacije između učesnika, koji utiču na društveni, kulturološki, institucionalni iekonomski aspekt uključujući $i$ aspekt prirodnih resursa što je karakteristika sektora šumarstva. Takva teorijski okvir omogućio je analizu stavova zaposlenih o vrsti $i$ značaju i fazi u kojoj se nalaze opaženi konflikti. Stavovi zaposlenih u preduzećima i organizacijama korisnicima državnih šuma, staraocima zaštićenih područja $i$ upravnim državnim organima iz sektora šumarstva, prikupljeni su anketnim upitnikom. Podaci su obrađeni deskriptivnom statistikom. Utvrđeno je dapostoji više konfliktnih situacija koje su svrstane u 10 grupa.Najznačajniji je koflikt između redovnih mera $i$ radova u šumi izaštita prirode. Uočeno je devet učesnika u konfliktnim sutuacijama. Utvrđeno je da su neki konflikti rešeni, dok su neki u latentnoj fazi, gde se može očekivati eskalacija.

Ključne reči: konflikt, šumarstvo, zaštita prirode

\section{INTRODUCTION}

Conflicts are as old as mankind. They are a general phenomenon that can occur in all life situations. Conflicts refer to a state of disagreement between individuals or groups of people, and they can be either destructive if they disturb the successful functioning of an individual, group or organization or constructive if they produce new ideas that can lead to the resolution. The absence of a conflict can be considered problematic as it indicates that the decision-making is centralized and there is only one 'truth` or that only one party is right (Hellström 2001)

According to "Vujaklija" Dictionary (1986), the word conflict is derived from the Latin word "conflictus" which means disagreement, collision, struggle, dispute, quarrel. For the purpose of this research, conflicts are defined as situations in which mutually dependent parties with opposing interests and goals act in a way that one party interferes with the actions of the other party (Hellström 2001). This definition contains the concepts of awareness, opposition, disturbance, and indicates that the conflict is intentionally provoked. Commonly used terms to express the concept of 'conflict' are struggle, pressure, opposition, aspirations, beliefs, interdependence, interaction, cooperation, rivalry, competition.

Scientific and professional literature views the conflict as an important factor of social and political change. By searching the Serbian citation index (SCIndex), 119 articles containing the term "conflict" were found (2010) and present in graph1.

Conflicts in the sector of forestry have been a topic of research in Serbia. So far, the sources of conflict have been identified in the forestry and environmental protection legislation (Poduška et al. 2008). Similar research studies point to environmental conflicts (Vuković 2008), analyzing conflicts over water. Malobabić (2003) points to environmental conflicts in rural areas by disputing the common opinion that rural areas are better-preserved environments. The autochthonous and healthy living environment of the village has been increasingly harmed by intensive farming based on chemical fertilizers and mechanization. On the other hand, villages still don't meet the utility standards, especially the ones related to water supply and drainage. Villages are also endangered by the traffic overload of 
public roads and inadequate house construction induced by the increasing demands of rural renewal.

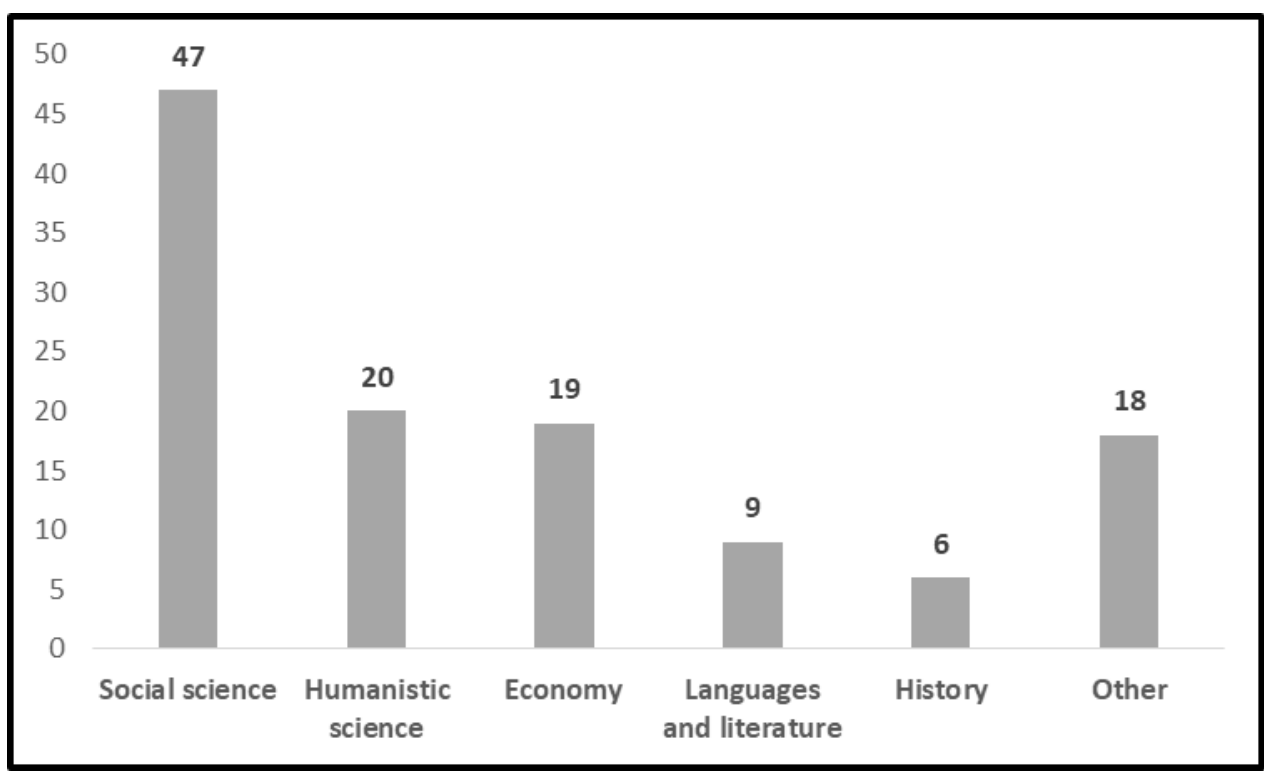

Graph 1. The number of articles in SCIndex containing the term 'conflict (2010)

The conflict between agriculture and the environment (Jevtić, Mirić 1991) was provoked by the market and social changes. It has been then escalating due to the growing demand for food, technological changes and the lack of alternative job offers in rural areas. 'It caused degradation of natural resources through deforestation, devastation and disturbance of the biological balance, as well as various types of pollution and contamination of the environment "(ibidem). Inadequate municipal waste management is a very common conflict in the territory of Serbia (Nenković-Riznić et al., 2009). Municipal waste affects the quality of water (Nikolić et al. 2010) and solid packaging becomes an environmental concern (Lazić et al. 2009). Due to the improper waste management, pollutants are released in the air, water and soil, which has adverse effects on human health and the environment (Šiljić et al. 2009, Curić 2009). Conflicting situations in protected natural resources are rooted in the technological development and entrepreneurial initiatives of private forest owners in national parks. The needs of rural and regional development opposed to the protection of nature in national parks can also be identified. (Grujičić et al., 2008, Milijić et al. 2009). Conflicts are also the consequence of spatial-environmental problems of industrial cities in transition (Spasić et al. 2009, Miletić et al., 2009).

The theoretical basis was found in "conflict triangle" (Walker, Daniels 1997) which enables us to recognize a conflicting situation by analyzing at least one of three conflict elements: the substance, the processes or the relations. This theoretical basis provides an analytical framework for data collection and analyze 
which can be applied in the forestry sector (Hellström 2001). Figure 1 shows the analytical framework of the research of conflicts in the forestry sector.

Figure 1. The analytical framework for collecting and analyzing data on conflicts in the forestry sector

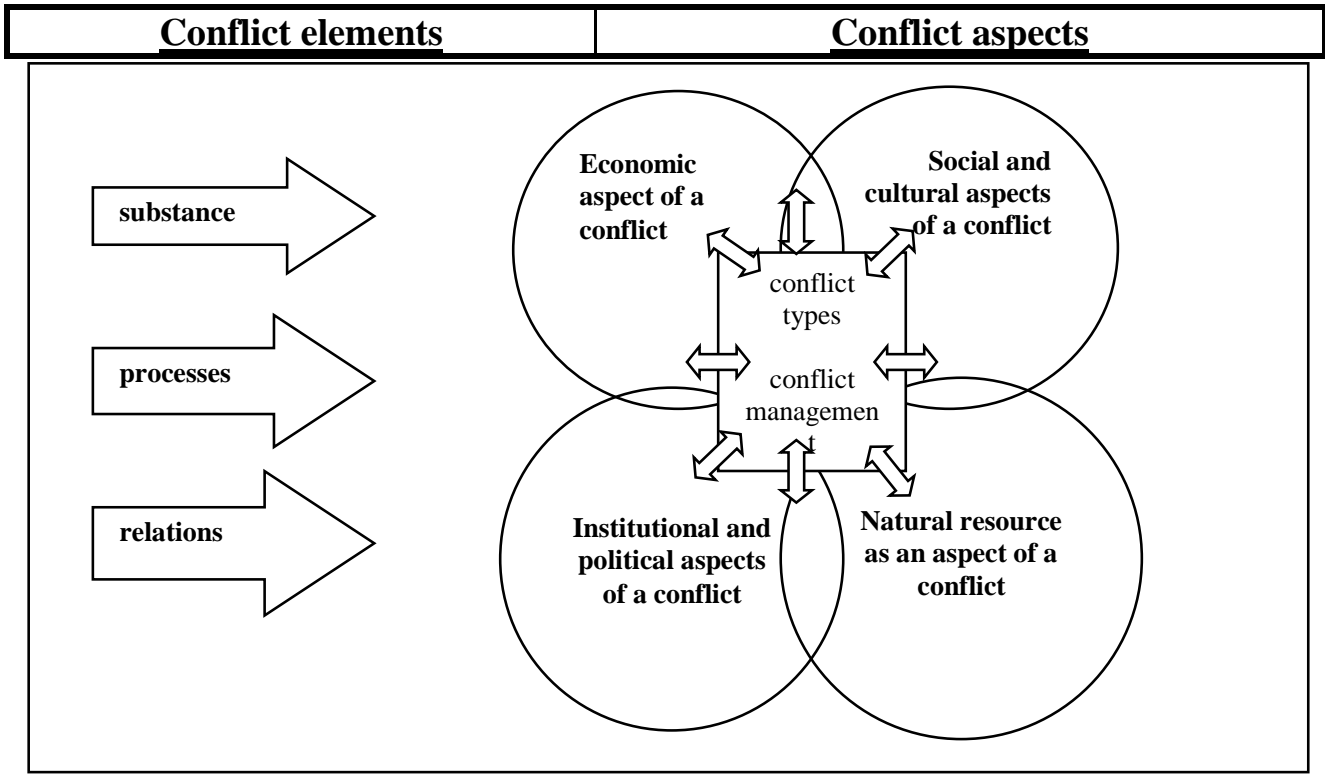

(Source: Helstrom 2001)

This analytical framework implies that each conflict consists of elements (substance, processes and relations) and different aspects of the conflict that determine the approach to conflict management. It has been noted that the relations are often so complex that prevent the conflicting situation from being resolved, but at the same time provide the basis for mediation and prevent further escalation. This analytical framework is suitable for the categorization and description of data on conflicts in the forestry sector. However, it does not provide an opportunity to define individual conflict situations (Hellström E. 2001).

Based on the adopted analytical framework, the aim and the purpose of the research were defined. The aim of the research was to identify the types of conflicts, the participants and the state of the observed conflicting situation. The purpose of the research was to get a deeper insight into the causes of conflict, the participants in the conflict, and the conflicting situation management and resolution.

\section{RESEARCH METHODS}

This research into the conflicts in the forestry sector applied the quantitative research approach, which involves the use of general and specific scientific methods (Šešić 1984; Mihajlović 2004; Miljević 2007). The statistical method, i.e., descriptive statistics was the general method used in the research. The purpose of this method was to collect and process data that can be expressed 
numerically. Specific methods included analysis, synthesis and generalization. Both primary and secondary data were collected. Primary data were collected through a survey. The population consist employees in from state forest enterprises, protected area managing companies and institutions engaged in the improvement of the natural resources management. To be more precise, the population included experts from state forest enterprises (SE) and forest governance institutions (Table 1). The sample consisted of employees in managerial positions or in the leading positions of respective organizational units. It included 160 experts in the field of forestry and nature protection. Respondents were interviewed using the Dillman survey method (Dillman 2007). Out of 160 surveys sent 109 were returned, which makes the return rate $68 \%$. The structure of respondents is shown in Table 1.

Table 1. Distribution of the surveys sent and returned

\begin{tabular}{|l|c|c|c|}
\hline Enterprise/Institution & $\begin{array}{c}\text { Sample } \\
\text { (number) }\end{array}$ & $\begin{array}{c}\text { Returned surveys } \\
\text { (number) }\end{array}$ & $\begin{array}{c}\text { Sample } \\
(\%)\end{array}$ \\
\hline SE "Srbijašume “and SE “Vojvodinašume“ & 142 & 98 & 69 \\
\hline Institute for Nature Conservation & 3 & 3 & 100 \\
\hline $\begin{array}{l}\text { National parks „Tara“, „,Kopaonik“, } \\
\text { „Đerdap“, „Fruška gora“ }\end{array}$ & 9 & 7 & 78 \\
\hline Forest Directorate & 6 & 1 & 17 \\
\hline \multicolumn{1}{|c|}{ Total } & $\mathbf{1 6 0}$ & $\mathbf{1 0 9}$ & $\mathbf{6 8}$ \\
\hline
\end{tabular}

Source: Author

The questionnaire had the following parts:

introductory text (intended for respondents). It described the research, provided information on the authors and the purpose of the research and reminded the respondents that their attitudes and answers would be completely anonymous;

- $\quad$ questions. Questions were the central part of the survey. They had their structure and position in the questionnaire. According to the structure of the questions, they were divided into i) introductory questions related to the age of the respondents, their education and work experience; ii) questions related to the types, intensity and frequency of conflict; iii) questions related to the management of conflicting situations and suggestions for the development of legislation and institutions in the forestry sector.

The survey was tested before its implementation. It was tested on a smaller group from the population. It was checked whether the respondents understood the questions and whether they were familiar with the topic of conflicts. Simple language was used without incomprehensible phrases and foreign words and expressions. Secondary data were obtained from professional and scientific literature and internet sources.

\section{RESULTS}

Through the analysis of the responses, we identified the type and significance of conflicts, the participants and the conflict stage. The third group questions reflected the views of the respondents on the type and significance of 
conflicts. Question 3 was an open-ended question where the respondents defined conflicts in forestry. The answers were encoded and grouped into 11 groups. They are shown in Table 2.

Table 2. Types of conflicts

\begin{tabular}{|c|l|c|}
\hline Code & Code meaning / Conflict Type and Significance & $\%$ \\
\hline 0 & No answer, I don`t know/ I don`t want to answer & 21 \\
\hline 1 & $\begin{array}{l}\text { Regular forest measures and works vs. property rights, cadaster, restitution of property to religious } \\
\text { communities }\end{array}$ & 19 \\
\hline 2 & Regular forest measures and works vs. disposal of financial resources, accounts ad encashment & 3 \\
\hline 4 & The impact of politics on the profession & 5 \\
\hline 5 & Forestry vs. Military polygons & 3 \\
\hline 6 & Users (managers) vs. contractors/ other forest users & 9 \\
\hline 7 & Non-compliance with spatial plans & 4 \\
\hline 8 & Regular forest measures and works vs. nature protection & 23 \\
\hline 9 & Forestry vs. tourism & 3 \\
\hline 10 & Regular forest measures and works vs. legislation & 6 \\
\hline 13 & Illegal logging & $\mathbf{1 0 0}$ \\
\hline & & \\
\hline
\end{tabular}

Source: Author

The relationship between regular forest measures and works and nature protection in protected areas (code 8) was emphasized as the most significant one (23\%). According to attitudes of $19 \%$ of respondents the conflict over property rights, including the restitution of forests to religious communities (code 1) were ranged on second place. The third most significant $(9 \%)$ was the conflict between the users of state forests or the managers of protected areas and contractors as well other forest users (code 6). These conflicts included disagreements with other forest users over tree cutting, production and transport of timber assortments and road maintenance as well as grazing and acorn collection. The opinion that there were disagreements over the implementation of regular forest measures and works and the legislation in the broadest sense (code 10) was given by $6 \%$ of respondents, while 5\% of respondents considered found the impact of daily politics and political organizations conflicting (code 4). According to the frequency of responses, the fifth group of conflicting situations included: non-compliance with spatial plans (code 7, 4\%), illegal logging (code 13; 3\%), disposal of financing resources (code $2,3 \%$ ), and forest and forest land use at sites of military polygons (code 5,3\%), as well as the impact of tourism, including the construction of ski tracks at sites managed by SE (code $9,3 \%$ ). No response was given by $21 \%$ of respondents, which can be interpreted that they either did not want to answer or did not encounter any conflicting situations at work.

Question 3b. defined the participants in the conflict (Table 3). There were three fields for the response so that the respondent could name more than two participants in the conflict. 
State enterprises for forest management (code 1) are the most frequent participants in the forestry sector conflicts $(44 \%)$.

Table 3. Participants in the forestry sector conflicts

\begin{tabular}{|r|r|c|}
\hline Code & \multicolumn{1}{|c|}{ Institution } & $\%$ \\
\hline 0 & No answer & 17 \\
\hline 1 & State forest enterprises & 44 \\
\hline 2 & Institute for Nature Conservation & 8 \\
\hline 3 & Courts & 1 \\
\hline 6 & Resposible Ministries & 5 \\
\hline 9 & Religious communities & 2 \\
\hline 10 & Private Forest Owners / local population & 5 \\
\hline 11 & Non-Governmental Organizations & 5 \\
\hline 12 & Local self-government & 5 \\
\hline 14 & Other enterprises managing protected areas & 7 \\
\hline
\end{tabular}

Source: Author

According to the responses, the Institute for Nature Conservation (8\%) and other enterprises of protected area management (7\%) make up the second group of participants in conflicts. The third group of conflict participants which accounts for $5 \%$ of the responses includes local self-governments, line ministries, NGOs and private forest owners or the local population. The share of religious communities as participants in the forestry sector conflicts amounts to $2 \%$ and these conflicts are due to the restitution processes initiated by the Church on the basis of the Law on Return of Property to Churches and Religious Communities (Off. Gazette 46/06). Courts account for $1 \%$ of all participants in conflicts.

The stage of conflict was examined by question 3c, where 5 responses and four graded stages of conflicts were given. The results are shown in the table.

Table 4. The stage of the conflict

\begin{tabular}{|c|l|c|}
\hline Code & The stage of the conflict & $\%$ \\
\hline 0 & No answer/ I don't know & 20 \\
\hline 1 & Latent conflict & 9 \\
\hline 2 & Occurring & 49 \\
\hline 3 & Escalating & 16 \\
\hline 4 & Solved & 6 \\
\hline \multicolumn{2}{r}{ Total } & $\mathbf{1 0 0}$ \\
\hline
\end{tabular}

Source: Author

The respondents believe that the conflicts are most often (49\%) in the "occurring" stage, which indicates that they are visible, in contrast to latent conflicts (9\%), which are not obvious. Respondents believe that there are $16 \%$ of escalating conflicts with an increasing level of disagreement between the participants. The resolved conflicts account for $6 \%$ of all conflicts. A fifth of the 
respondents did not give a response to the question, which can mean that they either did not want to answer it or they did not encounter a conflict or any of its stages.

\section{DISCUSSION AND CONCLUSIONS}

Forests are a renewable natural resource that provides numerous functions. These functions are mostly interrelated, but sometimes they can be congflicting too. These conflicting functions occurring at one site make forestry a specific economic activity. The most common and at the same time most opposing functions are the production and the protection ones. Out of the total area of state forests, production forests account for $63.16 \%$ compared to the protection forests that cover $36.18 \%$ of forest land (Medarević M. 2008). Forests should be exploited in such a way and scope that don't disturb their biodiversity, productivity, renewability, vitality and the potential to perform environmental, economic and social functions in the present and future. These requirements are included in the strategies and laws in the field of forestry and the environment. A large number of laws and by-laws, as well as different management objectives that are often complementary but sometimes competitive and conflicting, inevitably lead to the cohesion or collision in the sector. The impact of local population and nongovernmental organizations, as well as private forest owners and other forest users, should not be neglected. Requirements for the use of natural resources are often in opposition with the nature protection tendencies. Tree felling and utilization of forests and forest lands are constantly spotlighted by the general public, media, experts and researchers. Any disagreement over the use of natural resources leads to a conflicting situation. In this regard, it was entirely justified to carry out a survey in which forest users and forest owners would express their views on observed conflicts. It was found that conflicts were present in the forestry sector. A large number of users and owners of forests as well as managers of protected natural resources brings about overlapping interests. Property rights are a source of various conflicts between state forest users and private forest owners and between state-forest managing companies and institutions with overlapping competencies. National parks are a good example of a place where common user interests meet, overlap, and often conflict with the interests of other organizations and privateforest owners. This state of affairs is a research challenge with the aim of analyzing and describing mutual relations. Conflicts are sensitive topics that are difficult to understand and describe.

The common characteristics of the applied theory and the current situation in Serbia were observed. The obtained research results can be further interpreted based on the applied theory. In this regard, it can be pointed out that the conflicts are related to the lack of information, as well as wrong information and different interpretations of the available data. A lot of conflicts between forestry and nature protection are determined by the economic aspect. Owners or users of natural resources have the right to offer their property on the market, regardless of the category of protection or ownership relations. The economic aspect is inseparable from the political one since the sectoral policy decisions aim to reconcile the use of forests with the obligation to protect forests. The socio-cultural aspect indicates 
that the value of the forest is difficult to measure and compare with economic benefits. The forest is traditionally valued for its great importance for the owner or community. The parties in conflict have different scales of evaluation. What one party finds rational, the other one may find irrational. Natural resources are often a source of conflict. The reasons lie not only in the availability and sustainability of the resources but also in the social milieu and cultural heritage, economic and political situation, differences in people's opinion and expectations. The issue of ownership and legal property rights may often be a source of conflict. In forestry and nature protection, disagreements, conflicts and disputes occur between individuals, organizations and institutions dealing with forest management and those who manage protected areas.

A conflict can be managed and a conflicting situation solved only if all stakeholders are involved in decision making and the creation of long-term management plans (Niemela, J. et al., 2005). This is also indicated by the fact that there are $6 \%$ of resolved conflicts and $9 \%$ of the latent ones that we can consider to be upcoming, i.e. that can manifest in the future.

This research provided a better understanding of conflicts in the forestry sector. It was found that despite the existence of conflicting situations, they are viewed from different and often opposing stands. This means that the interpretation of the research results should rather provide an insight into the expert views on the observed conflicts, rather than means of controlling participants in conflicts. Future research should answer the question of how conflicts should be managed, whether they should be prevented or promoted and openly faced with.

\section{LITERATURE}

Curić, E. (2009). Problemi u odlaganju čvrstog komunalnog otpada u Novom Pazaru. Nauka + Praksa, 12(1), 13-17.

Dillman A. D., 2007: Mail and internet surveys - the tailored design method. Wiley, New York, 523.

Helström E., (2001). Conflict Culture - Qualitative Comparative Analysis of Envoronmental Conflicts in Forestry, Silva Fenica, Monographs 2, 109.p.

Jevtić, M., Mirić, M. (1991). Osnovne smernice agroekološkog razvoja u svetu i Jugoslaviji. Ekonomika poljoprivrede, 38(9), 441-448.

Lazić V., Gvozdenović, J., Popović, S. (2009). Ambalaža između potrebe i ekoloških problema. Časopis za procesnu tehniku i energetiku u poljoprivredi / PTEP, 13(3), 226-228.

Malobabić R. (2003). Problemi zaštite životne sredine u ruralnim područjima. Ecologica, 10(39-40), 61-70.

Medarević M., Banković S., Šljukić B., (2008). Održivo upravljanje šumama u Srbiji stanje i mogućnosti. Glasnik Šumarskog fakulteta, (97), 33-55.

Mihajlović D., (2004). Metodologija naučnih istraživanja. Beograd, Fakultet organizacionih nauka.

Milanović-Trailović M. (2009). Poslovanje na berzi i sudski sporovi. Pravo i privreda, 46(5-8), 528-542. 
Miletić R., Miljanović D., Todorović M. (2009). Industrijski gradovi u tranziciji problemska područja. Glasnik Srpskog geografskog društva, 89(3), 191-206.

Milijić V., Nonić D., Grujičić I., (2009). Vlasnici privatnih šuma i upravljanje zaštićenim područjima - nacionalni park Đerdap. Zaštita prirode, 60(1-2), 97-106.

Miljević M. (2007). Skripta iz metodologije naučnog rada. Pale, Univerzitet u Istočnom Sarajevu Filozofski Fakultet.

Nenković-Riznić M., Pucar M., Simonović S. (2009). Regionalni koncepti zaštite životne sredine i upravljanja otpadom na primerima Južnog Pomoravlja. Arhitektura i urbanizam, (26), 77-87.

Poduška Z., Rakonjac Lj., Gagić R., Petrović N., Čokić D., (2008). Stavovi prema regulativi šumarstva i životne sredine - pristup studije slučaja u Srbiji. Sustainable Forestry: Collection, (57-58), 124-136.

Niemela J., et al. (2005). Identifying, managing and monitoring conflicts between forest biodiversity conservation and other human interests in Europe, Elsvier, Forest Policy and Economics 7.

Nikolić V., Nikolić B., Sekulić L., Milovanović D., (2010). Kvalitet vode reke Ralje u gornjem i srednjem toku. Ecologica, 17(57), 48-52.

2010. Srpski citatni indeks. pristupljeno 18.12.2010. na adresi http://scindeks.nb.rs/.

Šešić B. (1988). Opšta metodologija. Beograd, Naučna knjiga.

Šiljić A., Ružić J., Knežević M., Maksimović A., Pocajt V., Ristić M. (2009). Očuvanje prirodnih resursa reciklažom materijala iz komunalnog otpada. Ecologica, 16(54), 169-172.

Spasić N., Džunić G., Đurđević J., (2009). Konflikti i ograničenja u prostornom razvoju rudarskih basena. Arhitektura i urbanizam, (27), 20-34.

Vuković M. (2008). Identifikacija konflikta oko vode i njegovo razrešenje. Facta universitatis - series: Philosophy, Sociology, Psychology and History, 7(1), 81-93.

Walker G.B., Daniels S.E., (1997). Foundation of natural resource conflict: Conflict theory and public policy. In Solberg B, and Miina S, (eds.) Conflict management and participation in land management (pp 7-36). European Forestry Institute Proceeding No. 14. Joensuu. Finland.

\title{
ATTITUDES OF EMPLOYEES ABOUT CONFLICTS IN THE FORESTRY SECTOR
}

\author{
Zoran PODUŠKA, Vlado ČOKEŠA, Ivana ŽIVANOVIĆ
}

\section{Summary}

Conflicts are as old as mankind. They are a general phenomenon that can occur in all life situations. Conflicts refer to a state of disagreement between individuals or groups of people, and they can be either destructive if they disturb the successful functioning of an individual, group or organization or constructive if they produce new ideas that can lead to the resolution. The theoretical basis was found in "conflict triangle" which enables us to recognize a conflicting situation by analyzing at least one of three conflict elements: the substance, the processes or the relations. Primary data were collected through a survey. It 
included 160 experts in the field of forestry and nature protection. It was found that there are 11 types of conflicting situations. The most important conflict is between regular measures and works in forest and nature protection. A conflict can be managed and a conflicting situation solved only if all stakeholders are involved in decision making and the creation of long-term management plans. This is also indicated by the fact that there are $6 \%$ of resolved conflicts and $9 \%$ of the latent ones that we can consider to be upcoming, i.e. that can manifest in the future.

\title{
STAVOVI ZAPOSLENIH O KONFLIKTIMA U SEKTORU ŠUMARSTVA
}

\author{
Zoran PODUŠKA, Vlado ČOKE ̌̌A, Ivana ŽIVANOVIĆ
}

\section{Rezime}

Konflikti su stari koliko i čovečanstvo. Opšta su pojava, koja se može dogoditi u svim životnim situacijama. To je stanje neslaganja između pojedinaca ili grupa ljudi, mogu biti destruktivni - koji ometaju uspešno funkcionisanje pojedinca, grupe ili organizacije ili konstruktivni kada se uočavanjem problema uvode nove ideje za njihovo rešavanje. Teorijska osnova nađena je u „konfliktnom trouglu“ gde je moguće prepoznati konfliktnu situaciju analizirajući bar jedan od elemenata konflikta: suštinu, proces ili relacije. Primarni podaci prikupljeni su putem anketnog upitnika. Uzorak se sastojao iz 160 stručnjaka u oblasti šumarstva i zaštite prirode. Utvrđeno je da postoji 11 tipova konliktnih situacija. Najznačajniji konflikt je između redovnih mera i radova u šumi i zaštite prirode. Upravljanje konfliktom u cilju rešavanja konfliktne situacije moguće je uključivanjem svih zainteresovanih strana u donošenju odluka i izradi dugoročnih planova gazdovanja. Na to nam ukazuje i rezultat da postoji $6 \%$ rešenih konflikta, ali i $9 \%$ latentnih koji možemo smatrati nadolazećim, odnosno koji mogu da se manifestuju u budućnosti. 